degree, in amyotrophic lateral sclerosis. The possibility that myelotoxic antibodies may be formed secondarily to myelin destruction, arising perhaps from some non-immune cause, is a very real one in view of the finding of antibody to encephalitogenic factor in a variety of neurological conditions reported by Field, Caspary, and Ball (1963). Nevertheless, their undoubted occurrence in multiple sclerosis and experimental allergic encephalomyelitis might well be of some pathogenetic importance because of the lowered blood-brain barrier at lesions in this disease (Broman, 1947, 1964) and in experimental allergic encephalomyelitis (Barlow, 1956 ; Vulpé, Hawkins, and Rozdilsky, 1960 ; Field, 1961).

Finally, the occurrence of two examples of myelotoxicity among our 20 normal sera should be compared with the 2 out of 26 reported by Bornstein and Appel (1965). Lumsden (1965) does not report upon normals, but in view of the findings of Hashem and Barr (1963) it is possible that normal subjects may become sensitized to brain or its degeneration products if these are ingested. The possibility exists also that laboratory workers or others habitually exposed to brain might show some antibody responses. In this connexion Field et al. (1963) were able to demonstrate antibody to an encephalitogenic factor in $20.4 \%$ of 44 normal subjects. There is, however, no evidence that human antibodies demonstrated by the tanned-cell method parallel serum myelotoxicity.

\section{Summary}

Serum from 13 out of 21 undoubted cases of motor neurone disease showed demyelinative activity (at one in four dilution) when allowed to act upon neonatal rat cerebellum cultures. Three out of five other cases in which the diagnosis was open to some doubt also showed this activity. Two out of 20 normal subjects also did so. All sera showed some degree of gliotoxic activity.

Myelotoxicity is not a property possessed exclusively by multiple sclerosis serum, though it may play a part in the pathogenesis of lesions.

We are much indebted to Dr. A. Vejiajiva, of the Department of Neurology, Royal Victoria Infirmary, for serum specimens from cases of motor neurone disease and for providing details of the clinical condition of the patients.

We would also like to thank Miss Greta Joyce, A.M.I.L.T., for histological preparations; and Miss Marjorie Hall, A.M.I.L.T., Miss Catherine Smith, A.M.I.L.T., and Miss Christine Colligan for their valuable technical help in preparing so many cultures.

\section{REFERENCES}

Barlow, C. F. (1956). F. Neuropath. exp. Neurol., 15, 196. Berg, O., and Källén, B. (1962a). Acta path. microbiol. scand., 54, 425. 1962b). Lancet, 1, 1051.

Bornstein, M. B. (1963). Nat. Cancer Inst. Monogr., No. 11, p. 197. - and Appel, S. H. (1961). F. Neuropath. exp. Neurol., 20, 141 - (1965). Ann. N.Y. Acad. Sci., 122, 280

Broman, T. (1947). Acta psychiat. scand., Suppl. No. 46, p. 58 Field (1964). Acta neurol. scand., Suppl. No. 10, p. 21. Field, E. J. (1961). Exp. Neurol., 4, 233.

Caspary, E. A., and Ball, E. Janet (1963). Lancet, 2, 11

Hashem, N., and Barr, M. L. (1963). Ibid., 2, 1029.

Lumsden, C. E. (1965). In Multiple Sclerosis-a Reappraisal by D. McAlpine, C. E. Lumsden, and E. D. Acheson. Livingstone, Edinburgh.

Vejiajiva, A., Foster, J. B., and Miller, H. (1965). Lancet, 1, 87.

Vulpé, M., Hawkins, A., and Rozdilsky, B. (1960). Neurology (Minneap.), 10, 171 .

\title{
Congenital Rubella Syndrome as a Systemic Infection. Studies of Affected Infants Born in Philadelphia, U.S.A.
}

\author{
J. M. LINDQUIST,* M.D. ; S. A. PLOTKIN, † M.D. ; L. SHAW,§ M.D. ; R. V. GILDEN,† PH.D. ; \\ M. L. WILLIAMS,* M.D.
}

[With Special Plate]

Brit. med. F., 1965, 2, 1401-1406

Since the teratogenic potential of the rubella virus was established by Gregg in 1941 a syndrome of maternal rubella in early pregnancy followed by congenital heart disease, cataracts, and deafness in the infant has often been described (Manson et al., 1960 ; Ingalls et al., 1960 ; Lündström, 1962). Although this classical triad of sequelae to intrauterine rubella infection is well documented, other anomalies have received less attention. Recently, the birth of a large number of American infants with a variety of congenital abnormalities has demonstrated that foetal damage associated with maternal rubella is not confined to a few defects. The damaged infants were born six to nine months after an epidemic of rubella that was widespread in the United States from the end of 1963 to the summer of 1964 (Morbidity and Mortality Weekly Report, 1964; Plotkin, 1964 ; Phillips et al., 1965). The congenital abnormalities which followed the epidemic included osseous lesions, hepatosplenomegaly, anaemia, and deficiency of megakaryocytes

\footnotetext{
* Department of Pediatrics, Philadelphia General Hospital. + The Wistar Institute.

The Children's Hospital of Philadelphia.

Department of Radiology, Philadelphia General Hospital.
}

in the bone-marrow. In addition, retardation of intrauterine growth, neonatal thrombocytopenic purpura, and rubelliform rash were seen with higher frequency than previously reported (Lündström, 1962 ; Berge et al., 1963).

With the aid of recently developed procedures for virus isolation (Weller and Neva, 1962 ; Parkman et al., 1962), Alford et al. (1964) showed that infants born after maternal rubella may excrete virus. In the recent epidemic their findings have been amply confirmed (Rudolph et al., 1965 ; Cooper et al., 1965 ; Plotkin et al., 1965 ; Rubella Symposium, 1965). In several instances individuals in contact with infants shedding virus have developed rubella, thus raising an important public health and epidemiological problem (Cooper et al., 1965).

The present paper reports the experience in a large city hospital in Philadelphia, Pennsylvania, during the period in which rubella-induced abnormalities were prevalent. Information is provided with respect to the incidence of congenital rubella syndrome in a predominantly negro population, the spectrum of anomalies in affected infants, the persistence of virus infection after birth, and the development of rubella antibodies. 


\section{Material and Methods}

The population surveyed for congenital defects included all infants born in Philadelphia General Hospital between April 1963 and March 1965. Between July 1964 and March 196540 newborn infants were selected for closer study because of the presence of congenital defects, in particular congenital heart disease or cataracts. Four infants born at other hospitals in the city were included. A negative history of maternal rubella did not exclude the infant from the study. It must be noted that there was no systematic questioning of mothers, so that the number of infants with positive maternal histories of rubella but without evident abnormality at birth is unknown.

Nose and throat cultures were obtained for virus isolation from all of the infants included in the study, usually within the first days of life. From some infants the first cultures were obtained later in life, the latest initial culture being obtained from a 5-month-old infant. Follow-up specimens for culture were subsequently obtained at irregular intervals. The presence of rubella virus was demonstrated by interference with the cytopathogenic effect of echovirus 11 in African green-monkeykidney cells (Parkman et al., 1962).

Blood was taken aseptically from each infant at the time of inclusion in the study and also at the age of 6 months.

Neutralization tests were performed according to a previously described protocol (Plotkin, 1964). Sera were treated with 2-mercaptoethanol according to the method of Deutsch and Morton (1957). For complement-fixation testing the method of Sever et al. (1965) was followed.

Additional clinical studies, including complete haemograms, bone-marrow examinations, spinal fluid examinations, and $x$-ray examinations were clone in selected infants with abnormalities warranting these investigations.

\section{Epidemiology}

\section{Results}

The population which Philadelphia General Hospital serves is predominantly negro. There are 5,200 deliveries a year at this hospital, an estimated one-third of the non-white births in the city. In order to discern the increase in congenital abnormalities produced by rubella in this population, defects of the heart or eye recognized in the neonatal period or early infancy during two successive 12-month periods were tabulated by month of the affected infant's birth. The first 12-month period, extending from April 1963 to March 1964, was considered as a control year. The second period, which extended from April 1964 to March 1965, included the period of epidemic congenital abnormality.

As presented in Table I, the data show a substantial increase in congenital defects of the heart and eye during the second 12 months and in particular between May 1964 and January 1965.

TABLB I.-Infants with Defects of the Heart or Eye Born Between April 1963 and March 1965, by Month of Birth

\begin{tabular}{cc|c|c|c|c|c|c|c|c|c|c|c|c|c|c|c}
\hline & & Apr & May & June & July & Aug & Sep & Oct & Nov & Dec & Jan & Feb & Mar & Total \\
\hline $1963-4$ & $\ldots$ & 1 & 2 & 2 & 1 & 1 & 1 & 0 & 2 & 1 & 1 & 2 & 2 & 16 \\
$1964-5$ & $\cdots$ & 1 & 5 & 3 & 7 & 4 & 3 & 4 & 7 & 4 & 10 & 2 & 2 & 52
\end{tabular}

During the first 12-month period there were 16 abnormal infants, or $0.31 \%$ of births, while during the second there were 52 abnormal infants, or $1.0 \%$ of births. Though data are available for only one control year, the probability that the difference between the two years is due to chance alone is less than 0.001 $\left(\chi^{2}=18.8\right)$.

\section{Clinical Findings}

There were 40 infants born with serious congenital abnormalities between July 1964 and March 1965. Data concerning 20 infants who had either positive virus isolation or a history of maternal rubella are presented in Table II. The infants listed in this table thus represent probable rubella syndrome.

The remaining 20 infants, most of whom had isolated cardiac disease, were excluded because of our inability to associate them with rubella.

A history of rubella or intimate exposure within the family was present in $16(80 \%)$ of the mothers of the infants in Table II. Fourteen mothers had a rubelliform illness in the first trimester and two were exposed to rubella in early pregnancy but did not develop symptoms of the disease. In three cases where mothers denied illness or exposure, rubella virus was recovered from the nasopharynx of the infants, implying that subclinical infection had occurred.

Rubella virus was isolated from the nasopharynx of $13(68 \%)$ of the 19 infants with probable rubella syndrome who were cultured. The relationship between frequency of virus isolation and age at the time of culture is shown in Table III. The percentage of infants from whom virus was isolated decreased with increasing age. While $77 \%$ of infants cultured in the first

TABLE II._Infants Born Between fuly 1964 and March 1965 with Clinical or Virological Features Suggestive of Congenital Rubella Syndrome (Probable Rubella Syndrome)

\begin{tabular}{|c|c|c|c|c|c|c|c|c|c|c|c|c|}
\hline Patient & $\begin{array}{c}\text { History of } \\
\text { Maternal } \\
\text { Rubella }\end{array}$ & $\begin{array}{c}\text { Isolation } \\
\text { of } \\
\text { Virus }\end{array}$ & $\begin{array}{c}\text { Congenital } \\
\text { Heart } \\
\text { Disease }\end{array}$ & Cataracts & $\begin{array}{c}\text { Low } \\
\text { Birth } \\
\text { Weight }\end{array}$ & $\underset{\substack{X \text {-ray } \\
\text { Changes }}}{x}$ & Anaemiat & $\begin{array}{l}\text { Thrombo- } \\
\text { cytopeniat }\end{array}$ & $\begin{array}{c}\text { Hepato- } \\
\text { splenomegaly }\end{array}$ & $\begin{array}{l}\text { Rash } \\
\text { at } \\
\text { Birth }\end{array}$ & $\underset{\text { Fontanelle }}{\text { Full }}$ & Died \\
\hline $\begin{array}{l}\text { G.W. } \\
\text { R.H. } \\
\text { J.A. } \\
\text { T.A. } \\
\text { C.F. } \\
\text { A.D. } \\
\text { J.J. } \\
\text { K.D. } \\
\text { S.M. } \\
\text { T.J. } \\
\text { B.I. } \\
\text { D.L. } \\
\text { A.L. } \\
\text { T.M. } \\
\text { S.R. } \\
\text { J.W. } \\
\text { D.W. } \\
\text { R.J. } \\
\text { R.G. } \\
\text { B.C. }\end{array}$ & $\begin{array}{c}3 \text { or } 4 \ddagger \\
? \\
2 \\
2 \\
2 \\
2 \\
1,2 \text { or } 3 \\
3 \text { or } 4 \\
\text { Denied } \\
3 \text { or } 4 \\
2 \text { or } 3 \\
\text { Denied } \\
1,2 \text { or } 3 \\
\text { Exposure } \\
1 \\
1,2 \text { or } 3 \\
\text { Exposure } \\
1 \\
1,2 \text { or } 3\end{array}$ & $\begin{array}{l}+ \\
+ \\
+ \\
+ \\
+ \\
+ \\
+ \\
+ \\
+ \\
+ \\
+ \\
+ \\
+\end{array}$ & $\begin{array}{l}\text { CoPA } \\
\text { PDAS } \\
\text { VSD/CoPA } \\
\text { VSDS } \\
\text { PDA\$ } \\
\text { AV Canal\$ } \\
\text { VSD } \\
\text { PDA\$/CoPA } \\
\text { PDAS/CoPA } \\
\text { PDA\$ } \\
\\
\text { AV Canal\$ } \\
\text { PDA\$/VSD } \\
\text { PS\$ } \\
\text { PDA\$ } \\
\text { VSD\$ }\end{array}$ & $\begin{array}{l}+ \\
\\
+ \\
+ \\
+ \\
+ \\
+ \\
+ \\
+\end{array}$ & $\begin{array}{l}+ \\
+ \\
+ \\
+ \\
+\end{array}$ & $\begin{array}{l}+ \\
+ \\
+ \\
+ \\
+ \\
+ \\
+ \\
+ \\
+ \\
+ \\
+\end{array}$ & $\begin{array}{l}+ \\
+\end{array}$ & $\begin{array}{l}+ \\
+ \\
+\end{array}$ & $\begin{array}{l}+ \\
+\end{array}$ & $\begin{array}{l}+ \\
+\end{array}$ & $\begin{array}{l}+ \\
+ \\
+ \\
+\end{array}$ & $\begin{array}{l}+ \\
+ \\
+ \\
+ \\
+\end{array}$ \\
\hline Incidence & $16(80 \%)$ & $13(68 \%)$ & $15(75 \%)$ & $12(60 \%)$ & $10(50 \%)$ & $10(50 \%)$ & $3(15 \%)$ & $4(20 \%)$ & $4(20 \%)$ & $3(15 \%)$ & $5(25 \%)$ & $6(30 \%)$ \\
\hline
\end{tabular}

Birth weight under $2,500 \mathrm{~g}$.
t Anaemia is defined as a haemoglobin less than $15 \mathrm{~g} . / 100 \mathrm{ml}$. during the first week of life; thrombocytopenia refers to a platelet count less than 75,000 c.mm. during the first two weeks of life.

$\neq$ Number refers to month of gestation.

₹ Number refers to month of gestation.

CoPA $=$ Coarctation of the pulmonary artery branches. PDA $=$ Patent ductus arteriosus. VSD = Ventricular septal defect. AV canal $=$ Endocardial cushion defect. PS $=\underset{\text { Pulmonary stenosis. }}{\text { Nc. }=\text { Not cultured. }}$ 
month of life were positive, the rate declined about $12.5 \%$ per month, so that no virus was isolated after the fifth month of life.

TABLE III.-Relation Between Age and Positive Virus Isolation in Infants Cultured Serially for Rubella Virus

\begin{tabular}{c|c|c}
\hline $\begin{array}{c}\text { Age in } \\
\text { Months }\end{array}$ & $\begin{array}{c}\text { Ratio of Positive Infants } \\
\text { to Total Cultured }\end{array}$ & $\begin{array}{c}\text { Percentage } \\
\text { Positive }\end{array}$ \\
\hline $0-1$ & $13 / 17$ & 77 \\
$2-3$ & $6 / 11$ & 55 \\
$4-5$ & $3 / 12$ & 25 \\
$>6$ & $0 / 9$ & 0 \\
\hline
\end{tabular}

Congenital heart disease, including patent ductus arteriosus, ventricular septal defect, coarctation of the pulmonary artery branches, endocardial cushion defect, and pulmonary stenosis, was present in $15(75 \%)$ of the infants with probable congenital rubella syndrome (Table II). Definitive diagnosis of these defects was established by cardiac catheterization and selective angiocardiography in 11 of the infants. Seven infants had patent ductus arteriosus, four of whom have required ligation because of intractable heart failure. In addition to patent ductus, two of the seven infants had coarctation of the pulmonary artery branches and one had ventricular septal defect. Ventricular septal defect was diagnosed in four other infants, one of whom also had coarctation of the pulmonary artery branches. In addition to the three infants with coarctation of the pulmonary artery branches previously mentioned, one infant had this lesion as an isolated defect following maternal rubella. Two infants with probable rubella syndrome had endocardial cushion defects. The only other cardiac lesion present in the probable rubella group of infants was pulmonary stenosis.

Cataracts were seen in $12(60 \%)$ of the infants in Table II but were obvious at birth in only three. Recognizable cataracts developed during the first weeks of life in the remaining nine infants. Surgical removal of the cataracts was often difficult because the irides were fibrotic and resistant to dilatation.

A birth weight under $2,500 \mathrm{~g}$. was noted in $10(50 \%)$ of the infants with probable rubella syndrome. Because of difficulty in obtaining exact histories of the last menstrual period it was not possible to define clearly which of the 10 infants were born prematurely and which showed the effects of intrauterine growth retardation. However, in at least six of the infants low birth weight was associated with a 38- to 40-week gestational age.

Many infants who were evaluated for congenital heart disease in the first weeks of life were noted to have irregular mineralization of the humeral metaphyses. Similar abnormalities were present in the metaphyses of all the long bones, most pronounced at the shoulders and the knees (see Special Plate). There were transverse radiolucent zones and longitudinal bands of demineralization alternating with areas of normal dense bone. Irregular zones of provisional calcification were noted in the femora, the pelvis, and the tarsal ossification centres. Of 20 infants in Table II, 10 (50\%) demonstrated osseous lesions, and two others had equivocal abnormalities.

Serial bone films obtained in several infants showed resolution of the abnormalities at 5 to 8 weeks of age. However, one infant (A. L.) with positive rubella isolation had radiographic abnormalities at 5 months of age. The presence of bone lesions prompted serum calcium, phosphorus, and alkaline phosphatase determinations in five infants. Unfortunately these studies were not obtained at the time of pronounced radiographic changes, but the results were normal during the resolution of the lesions.

Haematological abnormalities were noteworthy in the infants in Table II. Anaemia in association with thrombocytopenia was present in $3(15 \%)$ of the infants. One additional infant had thrombocytopenia without evidence of anaemia, bringing the incidence of the latter defect to $20 \%$ of the 20 infants. Examination of tibial marrow obtained from one infant (A.D.) on the eighth day of life showed a decrease in both erythropoietic tissue and megakaryocytes. Numerous osteoclasts were present (Fig. 1), suggesting osseous destruction. $X$-ray examination at this time revealed radiolucent zones in the metaphyses of the long bones. In a subsequent marrow examination at 5 weeks of age large numbers of osteoblasts were found, suggesting that regeneration of bone was taking place (Fig. 2). The marrow of another infant (K.D.) whose bone lesions were resolving also showed an increase in osteoblasts. A third anaemic infant in whom radiographic abnormalities of the bones were still present at 4 months of age did not have increased osteoblasts in a specimen of marrow.

Hepatosplenomegaly was present in four (20\%) infants, and a fifth (R. G.) had hepatomegaly associated with jaundice during the first week of life.

Rash occurred in 3 (15\%) of the infants with probable rubella syndrome (Table II). Two of these were thrombocytopenic, but whereas one had a purpuric rash, the other had a typical eruption similar to that seen in children or adults with rubella. The third infant, whose platelet count was normal, also had an erythematous macular rash. In all three infants the cutaneous findings were transient and had resolved by 1 wéek of age.

Central nervous system involvement in the form of a full anterior fontanelle was present in $5(25 \%)$ infants. In four there were no associated neurological abnormalities aside from irritability, and the cerebrospinal fluid was normal. One infant (R. J.) had severe convulsive seizures requiring treatment with barbiturates. The cerebrospinal fluid obtained from this infant at 1 day of age showed 115 white blood cells; $2,000 \mathrm{red}$ blood cells, and a protein of $170 \mathrm{mg} . / 100 \mathrm{ml}$. Though fullness of the fontanelle persisted for three weeks, pleocytosis disappeared in one week and no bacteria were ever isolated.

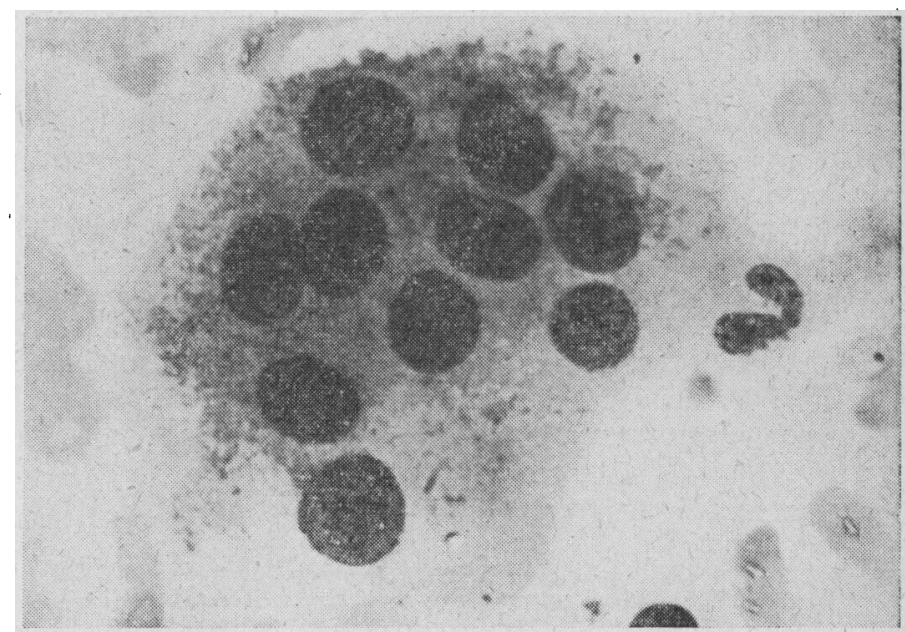

FIG. 1.-Osteoclast from tibial marrow of infant A. D. (Table II) at 8 days of age.

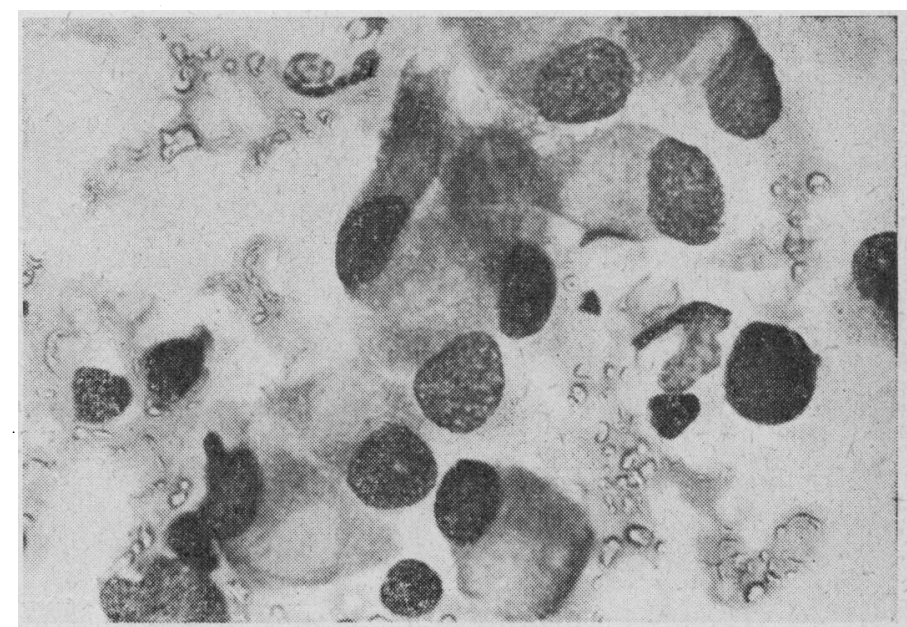

FIG. 2.-Osteoblasts in tibial marrow of infant A. D. at 5 weeks of age. 
Post-mortem examination of the brain of one 7-month-old infant (J. A., Table II) who showed poor growth and motor development revealed incomplete necrosis of the paraventricular white matter. Calcific concretions outlined the capillaries in the white matter, the corpus striatum, and some areas of cortex. Perivascular cuffing was absent. Microglial reaction in the form of rod cells was found in some of the lesions (Rorke, 1965). Brain tissue was unfortunately not cultured for rubella virus.

Six $(30 \%)$ of the infants in Table II died in early infancy. Two of them died suddenly at home at about 1 month of age: in one there was a 24-hour history of poor feeding and slight respiratory distress, whereas the other infant had been well after recovering from respiratory distress during the first week of life. One infant died in the hospital emergency room after the onset of acute dyspnoea at home. Three infants died in the hospital -one after cardiac surgery for repair of patent ductus arteriosus, one at 6 months of age after a period of chronic congestive heart failure and failure to thrive, and the third of purulent meningitis.

Owing to the young age of the infants we have no data regarding deafness.

\section{Serological Studies}

Serological studies were designed to answer the following questions: (1) How long do neutralizing antibodies persist after intrauterine rubella infection? (2) Does the foetus or newborn actively synthesize rubella neutralizing antibody? (3) Do rubella-syndrome infants develop complement-fixing antibodies ?

Insufficient time has elapsed to answer the first question. Neutralizing antibody determinations at 6 months of age are available for four infants with probable rubella syndrome, all of whom were positive at a level of $1 / 8$ or $1 / 16$.

In order to determine whether rubella antibody is in the IgM or IgG fractions of gamma-globulin, single serum specimens from 16 individuals were titrated with and without 2-mercaptoethanol treatment. Each pair of samples representing a single serum was titrated in the same neutralization test. Seven of the serum samples were collected from normal children during the first three days of life, while the other nine were obtained from children with rubella syndrome. In seven of the nine rubella-syndrome children, virus excretion was demonstrated in the nasopharynx.

The results of titration of 2-mercaptoethanol-treated and untreated sera from normal newborns are shown in Table IV.

TABLE IV.-Rubella Antibodies in Sera of Normal Newborns (0-3 Days Old) With and Without 2-Mercaptoethanol Treatment

\begin{tabular}{c|c|c}
\hline \multirow{2}{*}{ Infant } & \multicolumn{2}{|c}{ Rubella Antibody* } \\
\cline { 2 - 3 } & Untreated & ME-treated \\
\hline A & 64 & 64 \\
B & 16 & 16 \\
D & 32 & 128 \\
E & 64 & 64 \\
F & 64 & 32 \\
G & 16 & 8 \\
& 4 &
\end{tabular}

TABLE V.-Rubella Antibodies in Sera of Rubella Syndrome Infants With and Without Mercaptoethanol Treatment

\begin{tabular}{|c|c|c|c|c|}
\hline \multirow{2}{*}{ Infant } & \multirow{2}{*}{$\begin{array}{c}\text { Age } \\
\text { (Days) }\end{array}$} & \multirow{2}{*}{$\begin{array}{c}\text { Rubella } \\
\text { Virus } \\
\text { Isolation }\end{array}$} & \multicolumn{2}{|c|}{ Rubella Antibody* } \\
\hline & & & Untreated & ME-treated \\
\hline $\begin{array}{l}\mathbf{H} \\
\mathrm{I} \\
\mathrm{J} \\
\mathrm{K} \\
\mathrm{L} \\
\mathrm{M} \\
\mathrm{N} \\
\mathbf{O} \\
\mathbf{P}\end{array}$ & $\begin{array}{r}1 \\
3 \\
4 \\
4 \\
7 \\
9 \\
32 \\
36 \\
71\end{array}$ & $\begin{array}{l}+ \\
+ \\
+ \\
+ \\
+ \\
+ \\
+ \\
+ \\
+\end{array}$ & $\begin{array}{r}8 \\
128 \\
64 \\
32 \\
32 \\
32 \\
\geqslant 128 \\
64 \\
64\end{array}$ & $\begin{array}{r}8 \\
16 \\
32 \\
<8 \\
4 \\
<4 \\
32 \\
8 \\
16\end{array}$ \\
\hline
\end{tabular}

Treatment with 2-mercaptoethanol did not significantly lower the anti-rubella titre, and in one case seemed to increase the titre. Similar treatment of serum samples from nine infants with rubella syndrome (Table V) resulted in a fourfold or greater reduction in titre in seven. Reduction of antibody titre was shown in the sera of five infants shedding rubella virus and in two infants without demonstrable virus.

As shown in Table VI, only one of seven rubella-syndrome infants had complement-fixing antibodies to the virus. In contrast, convalescent sera from five children and adults with rubella were all positive.

TABLE VI.-Complement-fixation Tests for Rubella on Sera from Various Sources, Including Rubella Syndrome Infants

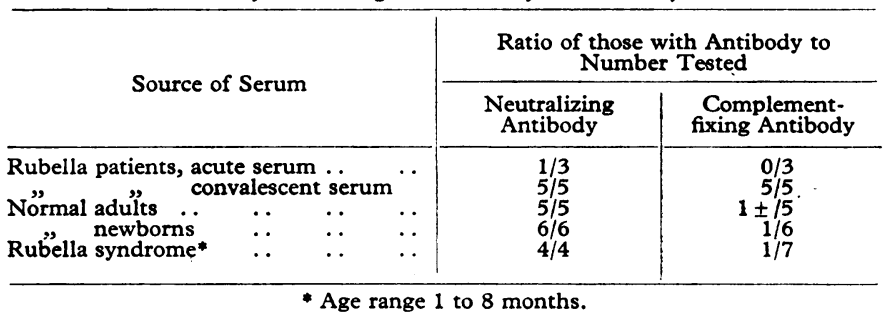

\section{Discussion}

The 20 infants presented here are representative of a larger number of abnormal infants born after a recent epidemic of rubella in the United States (Rudolph et al., 1965 ; Cooper et al., 1965 ; Plotkin et al., 1965 ; Rubella Symposium, 1965). In the current experience the congenital rubella syndrome was seen clearly to be a systemic infection resulting in more than the classic anatomic stigmata of cataracts, deafness, and congenital heart disease. Among the prominent clinical features in these infants, radiographic skeletal abnormalities were unique, but other findings of interest included anaemia, thrombocytopenia, purpuric rash, hepatosplenomegaly, and full anterior fontanelle.

Comparison of our results with two other studies of similar extent may be of value. Data on one series of infants were reported from Houston by Rudolph et al. (1965), while the second series was collected in Philadelphia (Plotkin et al., 1965). The findings made in the three studies, each comprising between 20 and 25 infants, are compared in Table VII. The figures are

TABLE VII.-Findings in Three Studies of Congenital Rubella Syndrome, 1964-5

\begin{tabular}{|c|c|c|c|c|}
\hline & & $\begin{array}{l}\text { Rudolph et al. } \\
\text { (1965). } \\
\text { Houston }\end{array}$ & $\begin{array}{l}\text { Plotkin et al. } \\
\text { (1965). } \\
\text { Philadelphia }\end{array}$ & $\begin{array}{c}\text { Present } \\
\text { Study. } \\
\text { Philadelphia }\end{array}$ \\
\hline 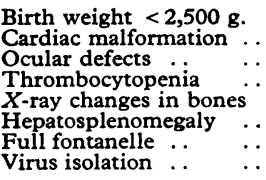 & $\begin{array}{l}\ldots \\
\cdots \\
\cdots \\
\cdots \\
\cdots\end{array}$ & $\begin{array}{l}80 \% \\
70 \% \\
44 \% \\
80 \% \\
60 \% \\
80 \% \\
44 \% \\
91 \%\end{array}$ & $\begin{array}{l}57 \% \\
67 \% \\
76 \% \\
43 \% \\
33 \% \\
33 \% \\
24 \% \\
90 \%\end{array}$ & $\begin{array}{l}50 \% \\
75 \% \\
60 \% \\
20 \% \\
50 \% \\
20 \% \\
25 \% \\
68 \%\end{array}$ \\
\hline
\end{tabular}

generally similar, but there are several apparent differences. The incidence of thrombocytopenia appears to be low in our study. Since platelet counts were not routinely done in the absence of a rash and the infants were negro, it is quite possible that some thrombyocytopenia was missed. More difficult to explain is the higher incidence of hepatosplenomegaly in Houston in relation to the two Philadelphia studies. The virus isolation rate was lower in this study than in the two others cited, but $68 \%$ compares favourably with results reported from New York (Cooper et al., 1965) and Cincinnati (Schiff et al., 1965).

Interstitial pneumonitis, hepatitis with jaundice, and myocardial necrosis have also been reported recently in association with intrauterine rubella (Rubella Symposium, 1965; Korones et al., 1965), but our group of infants did not provide good examples of these lesions. 


\section{E. J. FIELD AND D. HUGHES: TOXICITY OF MOTOR NEURONE DISEASE SERUM FOR MYELIN}

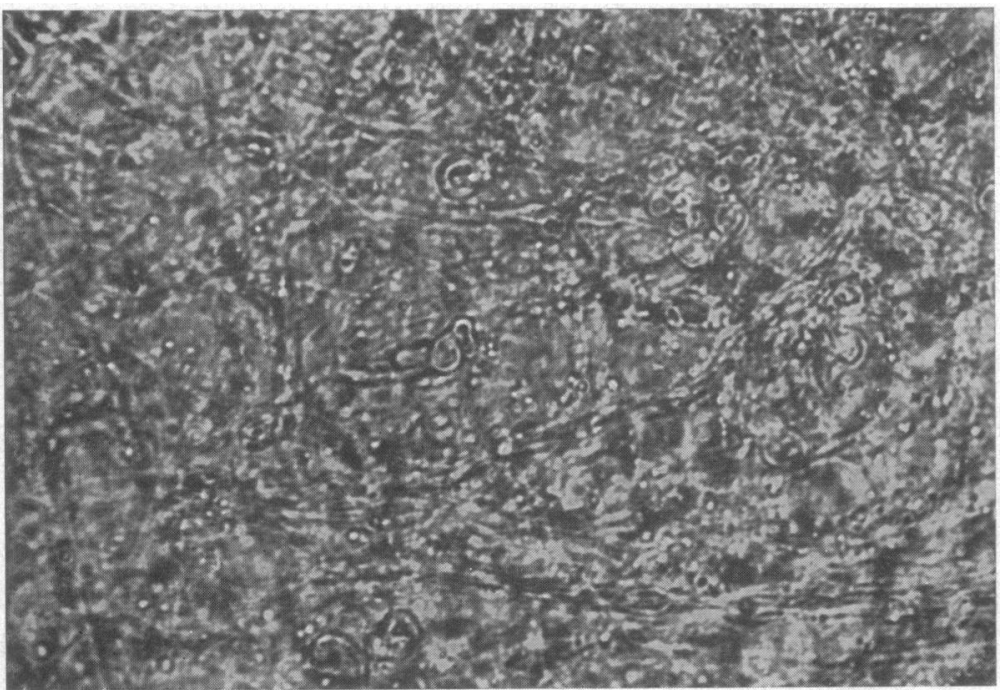

FIG. 5.- Same field at 69 hours, showing almost total disorganization of myelin. Nevertheless, axis cylinders are well preserved. $(\times 745$. $)$

FIG. 6.-Unharmed astroglial cells in culture which had been largely demyelinated by exposure to motor neurone disease serum (Figs. 1-5). These cells are more superficial in the culture and more towards the periphery. They are not actively associated with myelination. (Bodian stain. $\times 465$.)

FIG. 5

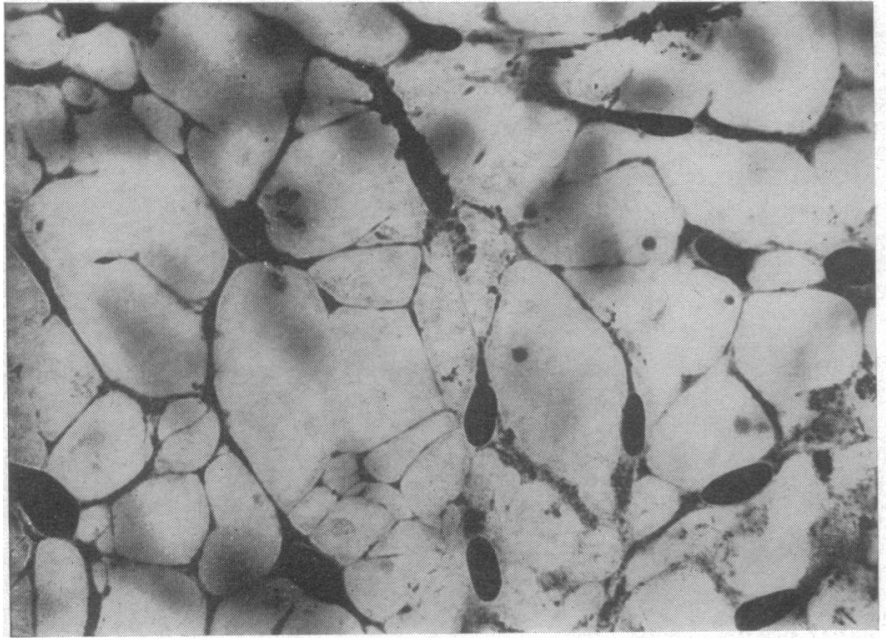

FIG. 6

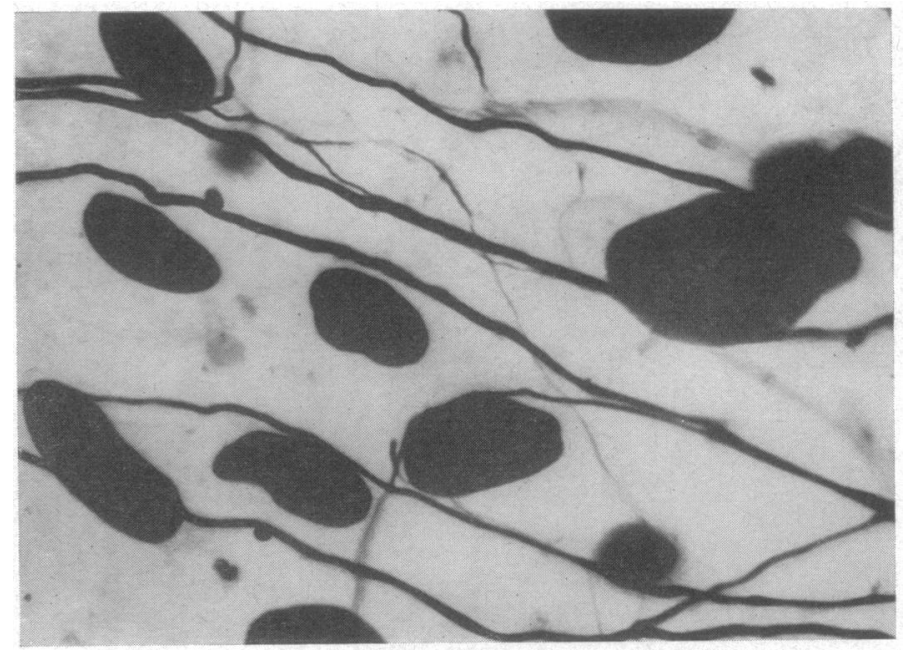

Fig. 7

J. M. LINDQUIST ET $A L$.: CONGENITAL RUBELLA SYNDROME AS A SYSTEMIC INFECTION

Typical $x$-ray appearance of the lower limbs in rubella-syndrome infants, showing metaphysial streaking and irregularity.

Fig. 7.-Culture shown in Figs. 1-5 (motor neurone disease serum test). Nerve fibres impregnated by Bodian's method. Despite the extensive demyelination, nerve fibres (and nerve cells) are unaltered. Both thick axons (which were heavily myelinated initially) and the non-myelinated fibres are preserved, glial nuclei are heavily impregnated. (Bodian stain. $\times 1,245$.) 
The variety of defects identified suggests that congenital rubella syndrome is an expression of generalized viral invasion and persistent multiplication of the agent in the tissues, as postulated by Selzer (1963). A number of related observations lend support to this hypothesis. Wide dissemination of the virus has been proved by its isolation from all organs of aborted foetuses and post-natally from the brain, lung, liver, and heart tissues of infants (Alford et 'al., 1964 ; Sever et al., 1964 ; Rubella Symposium, 1965 ; Plotkin, 1965). Changes in the walls of blood-vessels have been described which may reflect viral invasion. Campbell (1965) noted a deficiency of elastic tissue within the walls of the systemic and pulmonary arteries associated with intimal thickening in an infant with patent ductus arteriosus, coarctation of the pulmonary artery branches, and a history of maternal rubella. Areas in which there was elastic-tissue deficiency also showed intimal proliferation. The pathological changes observed in the brain of one of our infants may also reflect viral invasion of the tissue.

Proved viral osteitis had not been reported before this epidemic but must be regarded as the probable explanation for the bone lesions of these infants. These changes were generalized, involving all of the long bones, the pelvis, and the tarsal ossification centres. The predominance of the bone lesions in the metaphyses is consistent with the usual localization of osteomyelitis in children. The radiographic signs of bone destruction and the presence of increased numbers of osteoclasts in the marrow in the first weeks of post-natal life suggest the presence of active infection. The anaemia, thrombocytopenia, and purpura also may be expressions of infection of the bone-marrow. Rubella virus excretion can be demonstrated in most infants with bone changes, and, in addition, Zinkham and Medearis (1965) have reported virus isolation directly from the bone-marrow of eight infants.

In the present study virus recovery from the nasopharynx was most frequent just after birth and decreased regularly thereafter. One of our infants was still positive at 5 months of age, and other investigators have recovered virus from infants 9 months old (Cooper et al., 1965). Thus the maximum age of infection has yet to be determined, a fact of more than academic interest since contacts of infants excreting virus have developed rubella (Cooper et al., 1965). These infants are therefore possible sources of contagion in the hospital and potential hazards to pregnant women in the community. All infants exposed to rubella in utero should have serial cultures to determine when virus excretion ceases.

In Table II we have presented three instances of subclinical rubella infection of mothers. However, no attempt was made in our study to determine the extent of subclinical infection of newborns with rubella virus. An important report by Schiff et al. (1965) suggests that subclinical infection is considerable. Of 300 newborns at Cincinnati General Hospital who were tested for the presence of rubella virus, $43(14 \%)$ were found to be positive. Only 24 of the 300 infants, however, had a history of maternal rubella or abnormalities consistent with the rubella syndrome, and of these 10 were positive for rubella virus. More than three-fourths of the isolations (33) came from the 276 infants who had neither evident abnormalities nor a history of maternal rubella.

From our data it is possible to make a rough estimate of the incidence of rubella-induced anomalies. If it be assumed that the increase in defects shown in Table $I$ is entirely attributable to rubella, $0.69 \%$, or about 35 of the 5,200 infants born at Philadelphia General Hospital between April 1964 and March 1965 were affected by rubella virus. By projection of these rates to the total of approximately 15,000 negro births in Philadelphia, it can be computed that 105 infants were damaged by intrauterine rubella infection. These 105 infants presumably represent only $50 \%$ of those affected, since half the children with defects aetiologically related to rubella infection (such as deafness) are recognized later in childhood (Manson et al., 1960 ; Sheridan, 1964). Considering the extent of the epidemic, we conclude that about 210 (or $1.4 \%$ ) of Philadelphia negro infants in utero during the epidemic period were affected significantly by maternal rubella. Multiple factors may have contributed to increase the incidence of damaged infants in this population. A low level of health education was responsible for an unawareness of the significance of the disease during pregnancy. Late reporting to the physician prevented adequate documentation of the disease and eliminated the possibility of therapeutic abortion. The mildness of the illness and the ease with which a rash in the negro patient may be missed were additional factors.

Several types of serological studies were carried out on infants with rubella syndrome. Limited results available for neutralization tests support the previous observations (Plotkin et al., 1963 ; Weller et al., 1964 ; Dudgeon et al., 1964) that affected infants show persisting antibody.

Rubella antibodies in the sera of infants with rubella syndrome obtained in the first 10 weeks of life were shown to be partly destroyed by 2-mercaptoethanol treatment, implying that they are present in the IgM globulin fraction formed by the foetus as well as in the IgG fraction acquired from the mother. Foetal synthesis of rubella antibody thus begins either in the neonatal period or before birth.

The development of a complement-fixation test for rubella by Sever et al. (1965) has opened an important new avenue in the serological diagnosis of this disease. Complement-fixing antibodies appear during convalescence in the serum of children and adults. Unfortunately, our data show that infants infected with rubella virus in utero do not as a rule have complementfixing antibodies during the first eight months of life, and therefore cannot be identified by means of this test. Similar results have been obtained in Sever's (1965) laboratory.

\section{Summary}

A severe epidemic of rubella occurring throughout the United States in 1963 and 1964 was followed by the birth of many infants with-congenital abnormalities. Between July 1964 and March 196540 infants with serious abnormalities were born in a large general hospital in Philadelphia, Pennsylvania. On the basis of history of. maternal rubella, clinical features, and recovery of virus from the nasopharynx, 20 of the 40 infants were thought to be probable instances of rubella-induced damage. In addition to cataracts and heart disease, these infants showed signs of systemic infection, including lesions of the bones and bone-marrow.

The rate of virus isolation from the nasopharynx of rubellasyndrome infants was $77 \%$ in the first month of life and declined at a regular rate thereafter, approaching zero at 6 months of age.

Serological studies are reported concerning the presence of neutralizing- and the absence of complement-fixing antibodies in infants with rubella syndrome and the localization of neutralizing antibody to the macroglobulin fraction of serum protein.

We are grateful to Dr. Joseph Ritter for his advice and encouragement in this study. We are indebted to Dr. A. N. Moghadam for cardiac evaluation of the infants and to Dr. Elizabeth Mertens for her interpretation of the bone-marrow preparations.

This work was supported in part by grants from the Joseph P. Kennedy Jr. Foundation and from the United States Public Health Service (AI-01799).

\section{REFERENCES}

Alford, C. A., Neva, F. A., and Weller, T. H. (1964). New Engl. Y. Med., 271, 1275 . Med., 271, 1275.
Berge, Brunnhage, F., and Nilsson, L. R. (1963). Acta paediat.
(Uppsala), 52, 349.

Campbell, P. E. (1965). Brit. Heart F., 27, 134. 
Cooper, L. Z., Green, R. N., Krugman, S., Giles, J. P., and Mirick, G. S. (1965). Morbidity and Mortality Weekly Report, Communicable Disease Center, U.S. Public Health Service, 14, 44.

Deutsch, H. F., and Morton, J. I. (1957). Science, 125, 600.

Dudgeon, J. A., Butler, N. R., and Plotkin, S. A. (1964). Brit. med. 7., 2, 155 .

Gregg, N. M. (1941). Trans. ophthal. Soc. Aust., 3, 35.

Ingalls, T. H., Babbott, F. L., Hampson, K. W., and Gordon, J. E. (1960). Amer. F. med. Sci., 239, 363.

Korones, S., Ainger, L., and Roane, J. (1965). 75th Annual Meeting of the American Pediatric Society, Philadelphia, Pa. (Abstracts), p. 39. May, 1965.

Lündström, R. (1962). Acta paediat. (Uppsala), 51, Suppl. No. 133.

Manson, M. M., Logan, W. P. D., and Loy, R. M. (1960). Reports on Public Health and Medical Subiects, No. 101. H.M.S.O., London. Morbidity and Mortality Weekly Report (1964). Communicable Disease Center, U.S. Public Health Service, 13, 93.

Parkman, P. D., Buescher, E. L., and Artenstein, M. S. (1962). Proc. Soc. exp. Biol. (N.Y.), 111, 225 .

Phillips, C. A., Behbehani, A. M., Johnson, L. W., and Melnick, J. L. (1965). F.' Amer. med. Ass., i91, 615.

Plotkin, S. A. (1964). Ibid., 190, 265.

(1965). Unpublished data.

Dudgeon, J. A., and Ramsay, A. M. (1963). Brit. med. F., 2, 1296.

\author{
Oski, F. A., Hartnett, E. M., Hervada, A. R., Friedman, S., and \\ Gowing, J. (1965). 7. Pediat., 67, 182. \\ Rorke, L. (1965). Unpublished data. \\ Rubella Symposium (1965). 35th Annual Meeting of the Society for \\ Pediatric Research and the 75th Annual Meeting of the American \\ Pediatric Society, Philadelphia, Pa. (Abstracts), May, 1965. \\ Rudolph, A. J., Yow, M. D., Phillips, C. A., Desmond, M. M., Blattner, \\ R. J., and Melnick, J. L. (1965). F. Amer. med. Ass., 191, 843. \\ Schiff, G. M., Sutherland, J. M., Light, I. J., and Bloom, J. C. (1965). \\ 35th Annual Meeting of the Society for Pediatric Research, Phila- \\ delphia, Pa. (Abstracts), p. 47. May, 1965. \\ delphia, Pa. (Abstracts), p. 47.
Selzer, G. (1963). Lancet, 2, 336. \\ Sever, J. L. (1965). Personal communication. \\ Huebner, R. H., Castellano, G. A., Sarma, P. S., Fabiyi, A., Schiff, \\ G. M., and Cusumano, C. L. (1965). Science, 148, 385. \\ Schiff, G. M., Bell, J. A., and Huebner, R. J. (1964). F. Pediat., \\ 65, 1027 (Abst.). \\ Sheridan, M. D. (1964). Brit. med. F., 2, 536. \\ Weller, T. H., Alford, C. A., and Neva, F. A. (1964). New Engl. 7. \\ Med., 270, 1039. \\ - and Neva, F. A. (1962). Proc. Soc. exp. Biol. (N.Y.), 111, 215. \\ Zinkham, W. H., and Medearis, D. N. (1965). 75th Annual Meeting of \\ the American Pediatric Society, Philadelphia, Pa. (Abstracts), p. 2. \\ May, 1965.
}

\title{
Diagnostic Pneumoperitoneum in Amoebic Liver Abscess*
}

\author{
B. ELLMAN, $\dagger$ M.B., D.M.R.D. ; I. N. MCLEOD, $\ddagger$ M.D., F.C.P.(S.A.); S. J. POWELL,§ M.D., M.R.C.P.ED.
}

[With Special Plate]

Brit. med. F., 1965, 2, 1406-1407

In those regions where liver abscess is common the differentiation of a subphrenic source from primary pulmonary disease in the right lower zone of the chest is a frequent problem in diagnosis. The clinical features may be equivocal, and radiology is necessary to locate the precise anatomical site of such lesions. In Durban, where amoebic liver abscess is common among Africans, we have found that the conventional radiological techniques of postero-anterior and lateral films and of screening for diaphragmatic movement may not assist in distinguishing supradiaphragmatic right basal lung conditions from extension of a liver abscess through the diaphragm into the thorax. In some cases it is impossible to visualize the diaphragm adequately, and in other instances screening for diaphragmatic movement and estimation of diaphragmatic level has been found unreliable. At necropsy we have noted that extension of amoebic liver abscess into the thorax results in adhesions forming between the superior surface of the liver and the diaphragm. However, when an inflammatory process originates in the lung there is little tendency for downward extension to occur through the diaphragm and the liver remains free of adhesions. By delineating the superior surface of the liver and demonstrating the presence or absence of adhesions to the diaphragm, pneumoperitoneum, with carbon dioxide as contrast medium, offered a radiological method of potential diagnostic value. This paper reports our experience of such study.

Though the technique of pneumoperitoneal air insufflation was first described by Kelling (1902) and introduced to diagnostic radiology in 1910 , there has been some reluctance to employ it in diagnosis, possibly because of misapprehension regarding the complications. Initially air or oxygen was

* Requests for reprints of this paper should be addressed to Dr. S. J. Powell, Amoebiasis Research Unit, P.O. Box 1035, Durban, South Africa.

† Department of Radiology, University of Natal Medical School, Durban, South Africa. ¥Department of Medicine, University of Natal Medical School, Durban,

5 Department of Medicine, University of Natal Medical School, and Amoebiasis Research Unit, P.O. Box 1035, Durban, South Africa.

The Amoebiasis Research Unit is sponsored by the following bodies: the South African Council for Scientific and Industrial Research, the Natal Provincial Administration, the University of Natal, and the United States Public Health Service (Grant A1, 01592). employed as the gas medium, but in 1921 Alvarez introduced the use of carbon dioxide, thereby eliminating one of the major hazards of the procedure-namely, fatal air embolism. Stein (1951), reviewing the literature, concluded that the procedure was free from serious pleural and pulmonary complications.

\section{Material}

Thirty patients were selected in whom difficulty was being experienced in establishing a possible subphrenic cause of their disease. As the object of pneumoperitoneum was not to replace but to supplement the simpler techniques, only those patients were studied in whom the clinical findings, teleradiographs, and screening of the chest were equivocal or unhelpful in diagnosis. On clinical examination the majority presented with symptoms and signs of variable duration referable to the right lower chest and right upper quadrant of the abdomen. In some the abdominal signs were dominant, in others findings in the right lower chest predominated.

The primary object of pneumoperitoneum in each instance was to distinguish between supradiaphragmatic extension of an amoebic liver abscess and primary pulmonary or pleural disease by success or failure in demonstrating adherence between the superior surface of the liver and the diaphragm. Secondary objectives were to determine the position and contour of the diaphragm and to delineate any abnormalities in hepatic contour.

\section{Method}

Preliminary chest screening was carried out and control postero-anterior and lateral chest radiographs were taken. No pre-operative preparation other than sedation was required.

As many of the complications of pneumoperitoneum are related to faulty placement of the needle the abdomen was carefully palpated to ensure that no mass was present at the puncture site. Except when a mass or scar was present the site of election was 1 in. $(2.5 \mathrm{~cm}$.) to the left and 1 in. above or below the umbilicus. Under local anaesthesia the peritoneum was punctured by means of a short bevelled needle, and, to 